\title{
The Association between Elevated Carotid Intima-Media Thickness (CIMT) and Serum Uric Acid Levels among Patients with Essential Hypertension in Primary Care Setting.
}

\author{
Mohd Zulhilmie Mohd Nasir ${ }^{1}$, Khasnur Abd Malek ${ }^{1}$, Mohamad Rodi Isa ${ }^{1}$, Mohd Farhan \\ Hamdan $^{1}$, Roqiah Fatmawati Abdul Kadir ${ }^{1}$, Fauziah Ahmad ${ }^{2}$, and Wan Farzihan Wan \\ $\mathrm{Adib}^{2}$ \\ ${ }^{1}$ Universiti Teknologi MARA \\ ${ }^{2}$ Ministry of Health Malaysia
}

July 15,2020

\begin{abstract}
Aims: Our study aimed to investigate the relationships between elevated carotid-intima media thickness (CIMT) and serum uric acid (SUA) levels in hypertensive patients attending primary care clinics. Methods: We conducted a cross-sectional study on 140 hypertensive patients attending out-patient follow-up in two primary care clinics in Sungai Buloh, Malaysia, using a convenient sampling method. Serum uric acid levels were measured and divided into 4-quartile. Two radiologist specialists performed B mode ultrasonography to assess the right and left CIMT in all participants. Results: Participants' mean SUA level was $355.75 \pm 0.13$. Their mean age was 53.44 ( \pm 9.90$)$, with a blood pressure control of $137.09 \pm 13.22 / 81.89 \pm 8.95$. Elevated CIMT taken at [?]75th percentile was 0.666 for the left and 0.633 for the right common carotid arteries. Using multiple logistic regression, compared with the first quartile of the SUA level, the odd of elevated CIMT in quartile four in the common carotid artery was $(\mathrm{OR}=2.00 ; 95 \% \mathrm{CI}=0.64-6.27, \mathrm{p}=0.576)$ for the right and $(\mathrm{OR}=0.62 ; 95 \% \mathrm{CI}=0.20-2.00, \mathrm{p}=0.594)$ for the left. Waist circumference $(\mathrm{p}=0.001)$, body mass index $(\mathrm{p}=0.013)$, triglycerides $(\mathrm{p}<0.001)$ and high-density lipoprotein cholesterol $(\mathrm{p}=0.001)$ were significantly associated with the SUA quartiles. Conclusion: Although there was an increasing trend in the odd of elevated right CIMT across the SUA quartiles, this association, however, was not significant. Preventive effort to tackle the clustering effect of metabolic markers within this study population is needed to reduce the future risk of developing cardiovascular disease.
\end{abstract}

\section{Hosted file}

Full Manuscript.doc available at https://authorea.com/users/343070/articles/469758-theassociation-between-elevated-carotid-intima-media-thickness-cimt-and-serum-uric-acidlevels-among-patients-with-essential-hypertension-in-primary-care-setting

\section{Hosted file}

Table 1.docx available at https://authorea.com/users/343070/articles/469758-the-associationbetween-elevated-carotid-intima-media-thickness-cimt-and-serum-uric-acid-levels-amongpatients-with-essential-hypertension-in-primary-care-setting

\section{Hosted file}

Table 2.docx available at https://authorea.com/users/343070/articles/469758-the-associationbetween-elevated-carotid-intima-media-thickness-cimt-and-serum-uric-acid-levels-amongpatients-with-essential-hypertension-in-primary-care-setting 


\section{Hosted file}

Table 3.docx available at https://authorea.com/users/343070/articles/469758-the-associationbetween-elevated-carotid-intima-media-thickness-cimt-and-serum-uric-acid-levels-amongpatients-with-essential-hypertension-in-primary-care-setting

\section{Hosted file}

Figure 1.docx available at https://authorea.com/users/343070/articles/469758-the-associationbetween-elevated-carotid-intima-media-thickness-cimt-and-serum-uric-acid-levels-amongpatients-with-essential-hypertension-in-primary-care-setting

\section{Hosted file}

Figure 2.docx available at https://authorea.com/users/343070/articles/469758-the-associationbetween-elevated-carotid-intima-media-thickness-cimt-and-serum-uric-acid-levels-amongpatients-with-essential-hypertension-in-primary-care-setting 